Khaël VELDERS, Stijn JOYE, Daniël BILTEREYST, Thibault BONTE, Eveline DELCART

Ghent University, Belgium

\title{
(Un)covering Poland between PR and presidency. A quantitative content analysis of print news coverage of the Polish EU presidency in Flanders
}

\section{Introduction}

\begin{abstract}
A lthough international institutions and transnational governments have unmistakably played a prominent role in the global and local politics of recent years, European Union politics and governance have been and are still perceived by its citizens as remote and abstract (Blumler, 1983; Cini \& Borragán, 2013). News coverage of EU-related events and topics in the media, suggested by recent studies as providing the most important link between politics and citizens (Entman \& Bennett, 2001), could play a key role in the representation of the European Union and the further integration of its central government and its member states.

Acknowledging the importance of these dynamics, cross-national and longitudinal comparative research on the media coverage of EU-related news has gained increasing interest and momentum, but is still rare. The findings of these analyses indicate that news coverage of EU affairs is cyclical, peaking around key events (de Vreese et al., 2001; Norris, 2000). Trenz (2004), for one, argues that a European mediated public sphere has emerged while Leroy and Siune (1994) suggest a tendency to domesticate EU-related news, thus making it more relevant and appealing to local audiences. Peter, Semetko \& de Vreese (2003) conclude that this is not the case. They argue that these different findings may be the result of the fact that the study by Leroy and Siune (1994) analyzed news during a key event, while they focused on news coverage during a routine period. As the visibility of EU news has increased overall (Boomgaarden et al. 2012), there is little consensus on the status of European integration. Peter and de Vreese (2004, p. 3) thus conclude that
\end{abstract}


"[...] the Europeanization of television news coverage is more an illusion than reality."

Regardless of its outcome, the body of scholarly work on the news coverage of EU affairs is generally focused on the EU as an intergovernmental institution. While it does provide a clear view on the coverage of EU-related events in its respective member states, it largely remains ignorant of the particular flows of news in between the member states of the EU. The latter is the main concern of this article.

\section{Media coverage of the Polish EU presidency in Flanders}

The following analysis provides insight into the media coverage of the Polish EU presidency in the region of Flanders, the Dutch-speaking northern part of EU founding member - Belgium. For this quantitative content analysis, our scope is narrowed to three Flemish media sources: the broadsheet De Standaard, the popular newspaper Het Laatste Nieuws and the weekly magazine Knack. The denotation of 'popular newspaper' is not to be equated with the concept of a 'tabloid': while Het Laatste Nieuws does provide more coverage of topics related to sports and human interest, it still operates within the margins of 'midmarket' dailies by providing news reporting of political and socio-economic subjects and by appealing to a broad spectrum of the different social categories within the newspaper audience (De Bens \& Raeymaeckers, 2007).

Before moving on to the methodology and the subsequent discussion of our analysis results, it is important to note that the outcome of our quantitative analysis was similar to the research findings of a study performed by Joye (2010), illustrating the Eurocentric focus of Flemish news media. This longitudinal quantitative content analysis of foreign and international news in three Flemish newspapers demonstrated that only $0.98 \%$ of all news media attention was devoted to Poland over the period 1986 till 2006. Due to the comparable scarcity of attention observed in our own quantitative analysis, we have subsequently performed a qualitative analysis - which will however not be the subject of this paper - to complement the quantitative analysis results.

We collected the data by using the Mediargus database, an online search tool for archived newspaper articles, enabling us to search for references relevant in the context of this study. We used the keywords Polen, Pool, Pools and Poolse. These are the Dutch translations of the search 
terms Poland, Pole, Polish (male conjugation), and Polish (female conjugation). We restricted the scope of our search to three six-week periods: these three six-week periods covered data respectively from June 15, 2011 to July 31, 2011; from September 1, 2011 to October 15, 2011; and from December 1, 2011 to January 15, 2012. We gathered 735 news articles in total after inspection and deletion of duplicates. After the collection of the data, we followed up with a quantitative statistical analysis of the news articles by applying standard SPSS statistical tools. We have coded the news items based on an aggregated codebook, containing sixteen variables, which were distributed to the research teams that participated in the comparative study.

\section{Results}

News media

A first variable which has been analyzed, concerns the origin of the coded news articles $(n=735)$. Out of the 735 articles, 479 articles, or $65 \%$ of the data set, originated from the popular newspaper Het Laatste Nieuws, while 205 articles, or $27.9 \%$ of the items, were published in the broadsheet De Standaard. Only 51 news items, or 6.9\%, were gathered from Knack. These numbers are easily explained by pointing out that, in contrast to $D e$ Standaard and Het Laatste Nieuws, Knack is a magazine published on a weekly basis which severely limits its ability to report news with the same frequency as the selected newspapers. Furthermore, we would like to draw attention to the anecdotal observation that only one of all 735 coded articles appeared on the front page of one of the selected sources (i.e. De Standaard).

Size of the item

Table 1

Descriptives for size of news articles

\begin{tabular}{|c|c|c|c|c|c|c|c|c|}
\hline & \multirow{2}{*}{$\mathbf{N}$} & \multirow{2}{*}{ Mean } & \multirow{2}{*}{$\begin{array}{c}\text { Std. de- } \\
\text { viation }\end{array}$} & \multirow{2}{*}{ Std. error } & \multicolumn{2}{|c|}{$\begin{array}{l}95 \% \text { confidence } \\
\text { interval for mean }\end{array}$} & \multirow{2}{*}{$\begin{array}{l}\text { Mini- } \\
\text { mum }\end{array}$} & \multirow{2}{*}{$\begin{array}{c}\text { Maxi- } \\
\text { mum }\end{array}$} \\
\hline & & & & & $\begin{array}{l}\text { lower } \\
\text { bound }\end{array}$ & $\begin{array}{l}\text { upper } \\
\text { bound }\end{array}$ & & \\
\hline 1 & 2 & 3 & 4 & 5 & 6 & 7 & 8 & 9 \\
\hline De Standaard & 205 & 618.5317 & 566.67349 & 39.57819 & 540.4969 & 696.5665 & 52.00 & 3006.00 \\
\hline
\end{tabular}




\begin{tabular}{||l|c|c|c|c|c|c|c|c||}
\hline \multicolumn{1}{|c|}{1} & 2 & 3 & 4 & 5 & 6 & 7 & 8 & 9 \\
\hline $\begin{array}{l}\text { Het Laatste } \\
\text { Nieuws }\end{array}$ & 479 & 304.7349 & 250.76391 & 11.45770 & 282.2212 & 327.2485 & .00 & 2883.00 \\
\hline Knack & 51 & 1049.4314 & 909.97176 & 127.42153 & 793.4977 & 1305.3651 & 35.00 & 3265.00 \\
\hline Total & 735 & 443.9293 & 482.94778 & 17.81380 & 408.9572 & 478.9013 & .00 & 3265.00 \\
\hline
\end{tabular}

Table 2

One-way ANOVA for size of news articles

\begin{tabular}{|l|r|r|r|r|l||}
\hline & Sum of squares & df & Mean square & F & Sig. \\
\hline Between groups & 34228569.440 & 2 & 17114284.720 & 91.464 & .000 \\
\hline Within groups & 136968528.881 & 732 & 187115.477 & & \\
\hline Total & 171197098.321 & 734 & & & \\
\hline
\end{tabular}

Table 3

Posthoc Scheffe test for size of news articles

\begin{tabular}{||l|l|c|c|c|c|c||}
\hline \multirow{3}{*}{ (I) media } & (J) media & $\begin{array}{c}\text { Mean diffe- } \\
\text { rence (I-J) }\end{array}$ & Std. error & Sig. & lower bound & $\begin{array}{c}\text { 95\% confidence interval } \\
\text { uppeund }\end{array}$ \\
\hline \multirow{2}{*}{$\begin{array}{l}\text { De Standa- } \\
\text { ard }\end{array}$} & $\begin{array}{l}\text { Het Laatste } \\
\text { Nieuws }\end{array}$ & $313.79684^{*}$ & 36.10258 & .000 & 225.2457 & 402.3480 \\
\cline { 2 - 8 } & Knack & $-430.89967^{*}$ & 67.68818 & .000 & -596.9228 & -264.8765 \\
\hline \multirow{2}{*}{$\begin{array}{l}\text { Het Laatste } \\
\text { Nieuws }\end{array}$} & De Standaard & $-313.79684^{*}$ & 36,10258 & .000 & -402.3480 & -225.2457 \\
\cline { 2 - 8 } & Knack & $-744.69651^{*}$ & 63.71474 & .000 & -900.9737 & -588.4193 \\
\hline Knack & De Standaard & $430.89967^{*}$ & 67.68818 & .000 & 264.8765 & 596.9228 \\
\cline { 2 - 8 } & $\begin{array}{l}\text { Het Laatste } \\
\text { Nieuws }\end{array}$ & $744.69651^{*}$ & 63.71474 & .000 & 588.4193 & 900.9737 \\
\hline
\end{tabular}

* The mean difference is significant at the 0.05 level.

Using the size of the news articles as an indicator for the extensiveness of the news reporting, we are able to discern whether or not Knack is able to compensate for its limited frequency of coverage by providing a more in-depth analysis. The means of news article size for Het Laatste Nieuws $(\mathrm{m}=305)$,De Standaard $(\mathrm{m}=619)$ and Knack $(\mathrm{m}=1049)$ were analyzed using ANOVA $(\mathrm{p}<.05)$ and results of the analysis showed a significant difference between the groups $(F(2)=91,464$ and $p=.00)$. A posthoc Scheffe test $(\mathrm{p}<.05)$ was then performed to evaluate all possible pair-wise comparisons among means, showing significant results between all three news 
sources' means $(\mathrm{p}=.00)$. In summary, the data suggests that Knack provides significantly more in-depth analysis, compensating for its limited coverage. However, due to the great difference in variance, the inaccuracy of the observed results has to be taken into consideration.

\section{EU presidency relevance}

Thirdly, we analyzed the relevance of the news coverage of the EU presidency of Poland. The results of our analysis showed a severely low frequency of news items related to the EU presidency of Poland: no less than twelve, or $1.6 \%$, of all articles were coded as relevant. Of these twelve articles, only one item was published by Het Laatste Nieuws, while Knack and De Standaard respectively covered four and seven news items. Moreover, of these twelve articles, six were coded as published within the first seventeen days of the first six-week period (i.e. between June 15, 2011 and July 1, 2011). This timeframe coincides with the anticipation prior to the Polish EU presidency which came into effect on July 1, 2011. This observation could be interpreted as an illustration of the tendency of Western news media to focus on big news stories when covering foreign news (Hafez, 2007) and it illustrates the cyclical nature of news coverage of EU-related events (de Vreese et al., 2001; Norris, 2000). However, due to the very low frequency

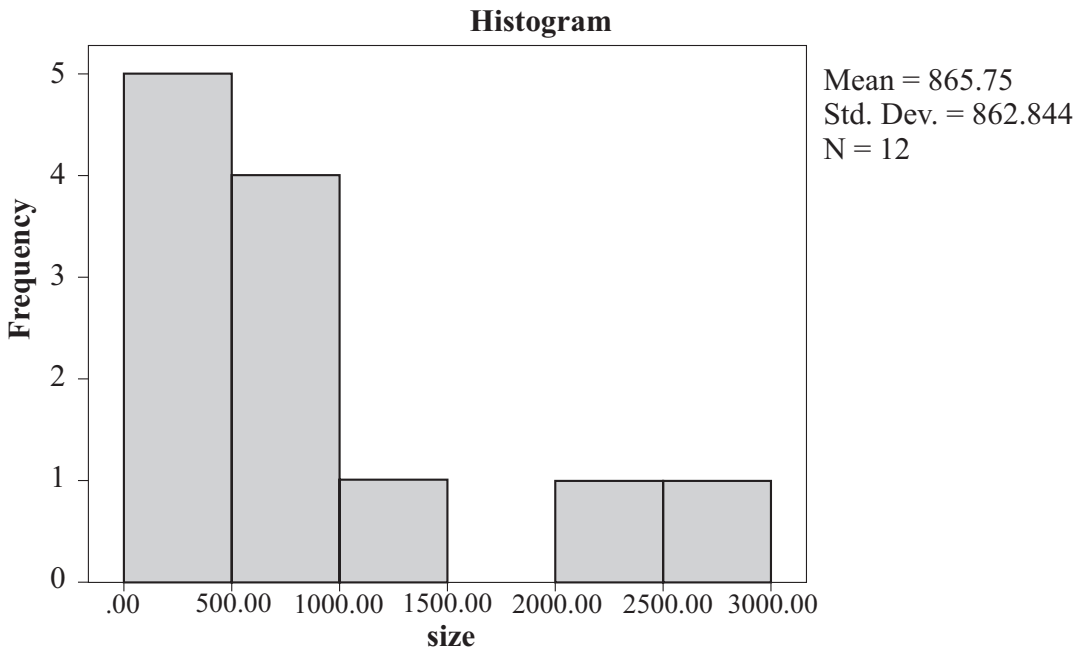

Figure 1. Distribution for size of relevant news articles 
of relevant news items it should be taken into consideration that this measurement might as well be incidental. Furthermore, in those items coded as relevant to the EU presidency, Poland's main role was mentioned mostly as an EU member. The distribution for the size of the articles within the selected relevant news items was analyzed and showed that five out of twelve of these articles did not exceed the limit of 500 words per article.

\section{Genre}

After our scrutiny of the variable of relevance, we broaden our scope back to the entire corpus of 735 articles. Concerning genre, analysis of the data set showed that 492 , or $66.9 \%$ of all items, were coded as news articles, while $20.8 \%$ and $5.4 \%$ were coded respectively as reports and interviews. These shares are similar for Het Laatste Nieuws and De Standaard, while a smaller amount of news articles in favor of a greater focus on interviews can be observed for Knack.

Table 4

Descriptives for genre of news articles

\begin{tabular}{||l|l|r|r|r|c|}
\hline \multirow{2}{*}{ Valid } & Frequency & Percent & Valid percent & $\begin{array}{c}\text { Cumulative } \\
\text { percent }\end{array}$ \\
\hline & news & 492 & 66.9 & 66.9 & 66.9 \\
\cline { 2 - 6 } & reportage & 153 & 20.8 & 20.8 & 87.8 \\
\cline { 2 - 6 } & editorial & 6 & .8 & .8 & 88.6 \\
\cline { 2 - 6 } & column & 10 & 1.4 & 1.4 & 89.9 \\
\cline { 2 - 6 } & commentary & 6 & .8 & .8 & 90.7 \\
\cline { 2 - 6 } & guest contribution & 13 & 1.8 & 1.8 & 92.5 \\
\cline { 2 - 6 } & interview & 40 & 5.4 & 5.4 & 98.0 \\
\cline { 2 - 6 } & letter to editor & 7 & 1.0 & 1.0 & 98.9 \\
\cline { 2 - 6 } & other & 8 & 1.1 & 1.1 & 100.0 \\
\cline { 2 - 6 } & Total & 735 & 100.0 & 100.0 & \\
\hline
\end{tabular}

Visual elements and relevance of visual elements to Poland

Furthermore, all news articles were analyzed for the presence of visual elements in the coverage. Out of all articles, 378 (51.4\%) contained a picture, while 321 articles (43.7\%) did not carry any visual elements at all. Only $62(8.4 \%)$ of all news items contained visual elements that are relevant to our object of inquiry, the Polish EU presidency. 


\section{Source of information}

Coding the source of information for the selected news articles proved to be a problematic exercise, as 591 (80.4\%) of the coded items did not mention its original source, preferring to cite the full name or initials of the news item contributor. Moreover, in 5\% of cases no source at all was mentioned. Comparing our three news sources, we observed that De Standaard mentioned its articles' sources noticeably more so than Het Laatste Nieuws and Knack. While still low in frequency, De Standaard referred to the source of information in $12.2 \%$ of the coded items compared to $1.2 \%$ and 4\% for Het Laatste Nieuws and Knack, respectively.

\section{Author of news and author of opinion}

The seventh variable for which the news articles were coded is the author of the item. For this variable, a distinction was made between an author of news and an author of opinion. News articles previously coded as news and reports for the genre variable were categorized as 'news material' and analyzed via the 'author of news' variable, whereas the items coded as all other genres - except for the genre 'other' - were categorized as 'not news material' and analyzed using the 'author of opinion' variable. The analysis of this latter category showed that different authors of opinion were somewhat equally distributed across the news items, the exception being national experts who accounted for $35.4 \%$ of the articles categorized as 'not news material'. For those articles classified as 'news material', the results were remarkably different: $95 \%$ of all news items had staff members identified as the authors of news, which is a logical consequence of the distribution across the variable for source of information (cf. supra).

\section{Dominant topic area}

All items were coded to discern exactly one dominant topic throughout the news article, the most recurring ones being sports (38.8\%), justice and crime (15.5\%), and culture (12.4\%). When comparing the distribution of dominant topics across the selected news sources, results showed that Het Laatste Nieuws accounted for $82.5 \%$ of all sports articles and for $78.1 \%$ of all justice and crime articles. These results correspond with Het Laatste Nieuws' profile as a popular newspaper in particular and the increasing 
tendency of tabloidization in general (De Bens \& Raeymaeckers, 2007). For the dominant topic of culture, most articles were gathered from $D e$ Standaard: this broadsheet newspaper accounted for 40 or $44 \%$ of the articles, while Knack and Het Laatste Nieuws accounted for $25.3 \%$ and $30.8 \%$, respectively. When narrowing our scope to the dominant topics recurring in the news articles related to the Polish EU presidency, we observe that six out of twelve articles refer to culture and four out of twelve items have to do with international politics. This is an interesting observation, as it demonstrates that even when news articles are considered relevant to the EU presidency of Poland, they are not necessarily political in nature but rather cultural (cf. infra).

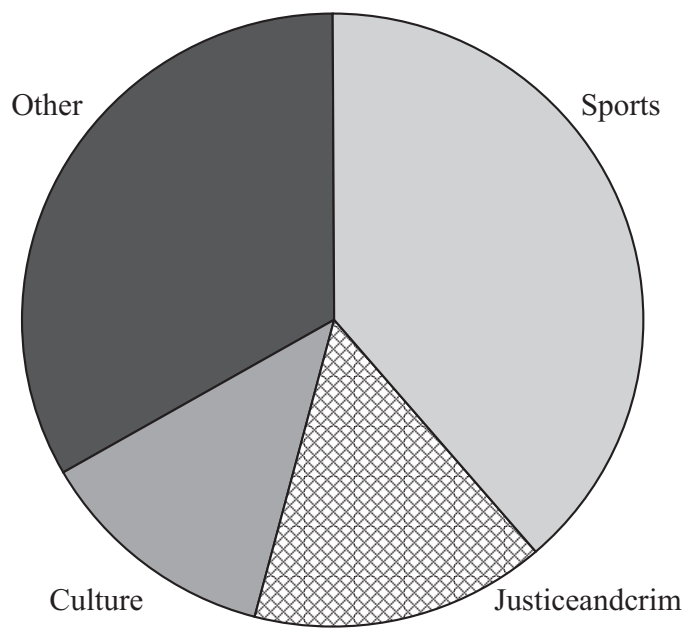

Figure 2. Distribution for dominant topic of news articles

Table 5

Cross tabulation of dominant topic and media source of news articles

\begin{tabular}{|c|c|c|c|c|c|c|}
\hline & & & \multicolumn{3}{|c|}{ Media } & \multirow[b]{2}{*}{ Total } \\
\hline & & & $\begin{array}{c}\text { De Stan- } \\
\text { daard }\end{array}$ & $\begin{array}{l}\text { Het Laats- } \\
\text { te Nieuws }\end{array}$ & Knack & \\
\hline 1 & 2 & 3 & 4 & 5 & 6 & 7 \\
\hline \multirow{4}{*}{$\begin{array}{l}\text { Domi- } \\
\text { nant } \\
\text { topic }\end{array}$} & \multirow{4}{*}{$\begin{array}{l}\text { internal } \\
\text { politics }\end{array}$} & Count & 7 & 2 & 2 & 11 \\
\hline & & $\%$ within dominant topic & $63.6 \%$ & $18.2 \%$ & $18.2 \%$ & $100.0 \%$ \\
\hline & & $\%$ within media & $3.4 \%$ & $0.4 \%$ & $3.9 \%$ & $1.5 \%$ \\
\hline & & $\%$ of total & $1.0 \%$ & $0.3 \%$ & $0.3 \%$ & $1.5 \%$ \\
\hline
\end{tabular}




\begin{tabular}{|c|c|c|c|c|c|c|}
\hline 1 & 2 & 3 & 4 & 5 & 6 & 7 \\
\hline & \multirow{4}{*}{$\begin{array}{l}\text { international } \\
\text { politics }\end{array}$} & Count & 12 & 3 & 6 & 21 \\
\hline & & $\%$ within dominant topic & $57.1 \%$ & $14.3 \%$ & $28.6 \%$ & $100.0 \%$ \\
\hline & & $\%$ within media & $5.9 \%$ & $0.6 \%$ & $11.8 \%$ & $2.9 \%$ \\
\hline & & $\%$ of total & $1.6 \%$ & $0.4 \%$ & $0.8 \%$ & $2.9 \%$ \\
\hline & \multirow[t]{4}{*}{ economy } & Count & 39 & 35 & 6 & 80 \\
\hline & & $\%$ within dominant topic & $48.8 \%$ & $43.8 \%$ & $7.5 \%$ & $100.0 \%$ \\
\hline & & $\%$ within media & $19.0 \%$ & $7.3 \%$ & $11.8 \%$ & $10.9 \%$ \\
\hline & & $\%$ of total & $5.3 \%$ & $4.8 \%$ & $0.8 \%$ & $10.9 \%$ \\
\hline & \multirow{4}{*}{$\begin{array}{l}\text { military and } \\
\text { defense }\end{array}$} & Count & 1 & 1 & 1 & 3 \\
\hline & & $\%$ within dominant topic & $33.3 \%$ & $33.3 \%$ & $33.3 \%$ & $100.0 \%$ \\
\hline & & $\%$ within media & $0.5 \%$ & $0.2 \%$ & $2.0 \%$ & $0.4 \%$ \\
\hline & & $\%$ of total & $0.1 \%$ & $0.1 \%$ & $0.1 \%$ & $0.4 \%$ \\
\hline & \multirow{4}{*}{$\begin{array}{l}\text { justice and } \\
\text { crime }\end{array}$} & Count & 24 & 89 & 1 & 114 \\
\hline & & $\%$ within dominant topic & $21.1 \%$ & $78.1 \%$ & $0.9 \%$ & $100.0 \%$ \\
\hline & & $\%$ within media & $11.7 \%$ & $18.6 \%$ & $2.0 \%$ & $15.5 \%$ \\
\hline & & $\%$ of total & $3.3 \%$ & $12.1 \%$ & $0.1 \%$ & $15.5 \%$ \\
\hline & \multirow[t]{4}{*}{ culture } & Count & 40 & 28 & 23 & 91 \\
\hline & & $\%$ within dominant topic & $44.0 \%$ & $30.8 \%$ & $25.3 \%$ & $100.0 \%$ \\
\hline & & $\%$ within media & $19.5 \%$ & $5.8 \%$ & $45.1 \%$ & $12.4 \%$ \\
\hline & & $\%$ of total & $5.4 \%$ & $3.8 \%$ & $3.1 \%$ & $12.4 \%$ \\
\hline & \multirow{4}{*}{$\begin{array}{l}\text { social } \\
\text { relations }\end{array}$} & Count & 9 & 18 & 4 & 31 \\
\hline & & $\%$ within dominant topic & $29.0 \%$ & $58.1 \%$ & $12.9 \%$ & $100.0 \%$ \\
\hline & & $\%$ within media & $4.4 \%$ & $3.8 \%$ & $7.8 \%$ & $4.2 \%$ \\
\hline & & $\%$ of total & $1.2 \%$ & $2.4 \%$ & $0.5 \%$ & $4.2 \%$ \\
\hline & \multirow{4}{*}{$\begin{array}{l}\text { science and } \\
\text { technology }\end{array}$} & Count & 3 & 0 & 0 & 3 \\
\hline & & $\%$ within dominant topic & $100.0 \%$ & $0.0 \%$ & $0.0 \%$ & $100.0 \%$ \\
\hline & & $\%$ within media & $1.5 \%$ & $0.0 \%$ & $0.0 \%$ & $0.4 \%$ \\
\hline & & $\%$ of total & $0.4 \%$ & $0.0 \%$ & $0.0 \%$ & $0.4 \%$ \\
\hline & \multirow[t]{4}{*}{ sport } & Count & 48 & 235 & 2 & 285 \\
\hline & & $\%$ within dominant topic & $16.8 \%$ & $82.5 \%$ & $0.7 \%$ & $100.0 \%$ \\
\hline & & $\%$ within media & $23.4 \%$ & $49.1 \%$ & $3.9 \%$ & $38.8 \%$ \\
\hline & & $\%$ of total & $6.5 \%$ & $32.0 \%$ & $0.3 \%$ & $38.8 \%$ \\
\hline & \multirow{4}{*}{$\begin{array}{l}\text { human } \\
\text { interest }\end{array}$} & Count & 11 & 25 & 4 & 40 \\
\hline & & $\%$ within dominant topic & $27.5 \%$ & $62.5 \%$ & $10.0 \%$ & $100.0 \%$ \\
\hline & & $\%$ within media & $5.4 \%$ & $5.2 \%$ & $7.8 \%$ & $5.4 \%$ \\
\hline & & $\%$ of total & $1.5 \%$ & $3.4 \%$ & $0.5 \%$ & $5.4 \%$ \\
\hline & \multirow{4}{*}{$\begin{array}{l}\text { accidents } \\
\text { and disasters }\end{array}$} & Count & 5 & 34 & 0 & 39 \\
\hline & & $\%$ within dominant topic & $12.8 \%$ & $87.2 \%$ & $0.0 \%$ & $100.0 \%$ \\
\hline & & $\%$ within media & $2.4 \%$ & $7.1 \%$ & $0.0 \%$ & $5.3 \%$ \\
\hline & & $\%$ of total & $0.7 \%$ & $4.6 \%$ & $0.0 \%$ & $5.3 \%$ \\
\hline
\end{tabular}




\begin{tabular}{|c|c|c|c|c|c|c|}
\hline 1 & 2 & 3 & 4 & 5 & 6 & 7 \\
\hline & \multirow[t]{4}{*}{ other } & Count & 6 & 9 & 2 & 17 \\
\hline & & $\%$ within dominant topic & $35.3 \%$ & $52.9 \%$ & $11.8 \%$ & $100.0 \%$ \\
\hline & & $\%$ within media & $2.9 \%$ & $1.9 \%$ & $3.9 \%$ & $2.3 \%$ \\
\hline & & $\%$ of total & $0.8 \%$ & $1.2 \%$ & $0.3 \%$ & $2.3 \%$ \\
\hline \multirow[t]{4}{*}{ Total } & Count & 205 & 479 & 51 & \multicolumn{2}{|c|}{735} \\
\hline & $\begin{array}{l}\% \text { within do- } \\
\text { minant topic }\end{array}$ & $27,9 \%$ & $65.2 \%$ & $6.9 \%$ & \multicolumn{2}{|c|}{$100.0 \%$} \\
\hline & $\begin{array}{l}\text { \% within } \\
\text { media }\end{array}$ & $100,0 \%$ & $100.0 \%$ & $100.0 \%$ & \multicolumn{2}{|c|}{$100.0 \%$} \\
\hline & $\%$ of total & $27,9 \%$ & $65.2 \%$ & $6.9 \%$ & \multicolumn{2}{|c|}{$100.0 \%$} \\
\hline
\end{tabular}

Domestication and dateline

Table 6

Descriptives for domestication of news articles

\begin{tabular}{|l|l|r|r|r|c||}
\hline \hline \multicolumn{2}{||c|}{} & Frequency & Percent & $\begin{array}{c}\text { Valid } \\
\text { percent }\end{array}$ & $\begin{array}{c}\text { Cumulative } \\
\text { percent }\end{array}$ \\
\hline \multirow{4}{*}{ Valid } & explicit reference to nationals & 628 & 85.4 & 85.4 & 85.4 \\
\cline { 2 - 6 } & explicit reference to impact & 5 & .7 & .7 & 86.1 \\
\cline { 2 - 6 } & $\begin{array}{l}\text { reference to nationals and vi- } \\
\text { sual elements }\end{array}$ & 3 & .4 & .4 & 86.5 \\
\cline { 2 - 6 } & no & 99 & 13.5 & 13.5 & 100.0 \\
\hline & Total & 735 & 100.0 & 100.0 & \\
\hline
\end{tabular}

We coded and analyzed the data set for dateline and domestication, two variables closely related to one another. The most frequently recurring dateline was Belgium, which was mentioned in 453 news articles or $61.6 \%$ of the data set. A noticeable gap was observed between this and the next dateline, namely Poland, which accounted for $14 \%$ of the news items. Focusing on the domestication variable, we are able to discern that 628 or $85.4 \%$ of all news articles made an explicit reference to national or domestic issues and persons. This finding is consistent with previous studies on international news reporting in Flemish media (cf. Joye 2010) which have all identified the broad concept of proximity as a key news value.

\section{Main role of and attitude towards Poland}

Finally, a short word on the role of and the attitude towards Poland in the analyzed news items. Only in eight out of 735 items, or $1.1 \%$, was Po- 
land mentioned as an EU member. Furthermore, Poland was only cited as the host of an EU-related meeting in two news articles. Nearly every news item, accounting for $98.4 \%$, was coded as 'other' regarding its attitude toward Poland. This does not imply a neutral attitude, but rather a complete absence of any subjectivity in news reporting on Poland or its EU presidency.

\section{Conclusion}

Drawing on the aforementioned results enables us to get a clearer picture of the news flow on the Polish EU presidency from Poland to Belgium. Most importantly, we have observed that the analyzed news sample has devoted little attention to the Polish EU presidency. Moreover, the coverage of this topic is concentrated around the Polish EU presidency coming to effect. News items relevant to the EU presidency of Poland were limited in size and did not provide a focused analysis, favoring objective news reporting with absence of a discernible attitude towards Poland. Articles relevant to the presidency were not necessarily political of nature: in half of the cases the dominant topic of the news items was culture.

Taking into consideration the entire sample set of articles, the topics of sports, culture, and justice and crime dominate the news output. This may be explained by the origin of the sampled news articles: two thirds of all articles originate from the popular newspaper Het Laatste Nieuws, which has been shown to favor coverage of these news genres. Our analysis further serves as a contemporary illustration of the often cited dynamics of domestication of foreign news (Gurevitch et al., 1991).

\section{References}

Bennett W. L., Entman R. M. (2001), Mediated Politics: Communication in the Future of Democracy, Cambridge University Press, Cambridge.

Blumler J. G. (1983), Key features of research design, in: Communicating to voters: Television in the first European parliamentary elections, pp. 25-37.

Boomgaarden H. G., Vliegenthart R., de Vreese C. H., Schuck A. R. T. (2010), News on the Move: Exogenous Events and News Coverage of the European Union, "Journal of European Public Policy", no. 17(4), pp. 506-526.

Cini M., Borragán N. P. (2013), European Union Politics, Oxford University Press, Oxford. 
De Bens E., Raeymaeckers K. (2007), De pers in België, Lannoo Campus, Leuven. de Vreese C. H., Peter J., Semetko H. A. (2001), Framing Politics at the Launch of the Euro: A Cross-national Comparative Study of Frames in the News, "Political Communication", no. 18(2), pp. 107-122.

Gurevitch M., Levy M., Roeh I. (1991), The Global Newsroom: Convergences and Diversities in the Globalization of Television News, in: Communication and Citizenship. Journalism and the Public Sphere in the New Media Age, eds. P. Dahlgren, C. Sparks, Routledge, London, pp. 195-216.

Hafez K. (2007), The Myth of Media Globalization, Polity Press, Cambridge.

Joye S. (2010), Around the world in 8 pages? A longitudinal analysis of international news coverage in Flemish newspapers (1986-2006), Academia Press, Gent.

Leroy P., Siune K. (1994), The role of television in European elections: The cases of Belgium and Denmark, "European Journal of Communication", no. 9(1), pp. $47-69$.

Norris P. (2000), A Virtuous Circle: Political Communication in Post-Industrial Democracies, Cambridge University Press, Cambridge.

Peter J., de Vreese C. H. (2004), In Search of Europe: A Cross-National Comparative Study of the European Union in National Television News, "The Harvard International Journal of Press/Politics", no. 9(4), pp. 3-24.

Peter J., Semetko H. A., de Vreese, C. H. (2003), EU Politics on Television News A Cross-National Comparative Study, "European Union Politics", no. 4(3), pp. 305-327.

Trenz H. J. (2004), Media Coverage on European Governance: Exploring the European Public Sphere in National Quality Newspapers, "European Journal of Communication", no. 19(3), pp. 291-319.

\begin{abstract}
Cross-national and longitudinal comparative research on the media coverage of EU-related news has gained increasing interest and momentum, but is still rare and generally focuses on the EU as an intergovernmental institution, hence remaining largely ignorant of the particular flows of news in between the member states of the EU. The following analysis provides insight into the media coverage of the Polish EU presidency in the region of Flanders. For this quantitative content analysis, our scope is narrowed to three Flemish media sources. Based on a predetermined set of keywords related to the Polish case and using the newspaper search engine Mediargus, we collected 735 articles for analysis. In conclusion, the analyzed news sample devoted little attention to the Polish EU presidency. News items relevant to Poland's presidency of the EU were concentrated around the presidential inauguration, limited in size, not necessarily political in nature, and favored objective news reporting with absence of a discernible attitude towards Poland.
\end{abstract}

